\title{
hikaayaat kaliila wa-dimna li-tulaab al-lughat al-'arabiyya (Tales from Kalila wa Dimna for Students of Arabic [retold])
}

\author{
Munther A Younes \\ Ithaca, NY: Spoken Language Services, 2001. \\ 206 pages, 3 audio $C D$ s.
}

The title Kalila wa Dimna first came to my attention long ago in my second year of Arabic language study. Ahmad Amin mentions Kalila wa Dimna in passing in his autobiography, Hayati (Cairo: 1952), an excerpt of which I read in Farhat Ziadeh's Reader in Modern Literary Arabic. Over the years, I tried occasionally to read a bit of the original and found the classical Arabic intimidating. The task of reviewing Munther Younes's retelling of these stories represented the opportunity to taste the stories' flavor without the drudgery of dictionary look-up. Among other accomplishments, Younes simplifies the grammar and lexicon to the point where intermediate students of Arabic will understand what they read without excessive struggle. This review will touch upon the structure and substance of Kalila wa Dimna itself and Younes' approach to retelling the stories and their utilization as an Arabic language teaching tool.

In the West, most of us hear and then read Aesop's Fables as children. These stories, which date back as far as $620 \mathrm{BCE}$, feature anthropomorphic animals who play out their dramas and conflicts in order to teach a moral. Kalila wa Dimna, attributed to the Indian author Bidpai and written in Sanskrit during the third century, does much the same, but also includes a smattering of human characters. As Younes tells us, the Sassanid King Khosro Anoushrawan sent his physician Burzuwayh to India to collect and translate Bidpai's fables into Persian. In the process, Burzuwayh added stories by other authors. What had now become a book was then translated into Syriac in 570; 200 years later, Abdullah ibn al-Muqafa ${ }^{c}$ translated it into Arabic. Since its Arabization some 12 centuries ago, Kalila wa Dimna 
has held a place of honor in the Arab world among those who read the written word and those who enjoy literature in its oral traditions.

Kalila and Dimna are two jackals who populate one of the book's many continuing and interrelated stories. Dimna uses his wiles to ingratiate himself with King Lion, and deceives him into killing his (the king's) own best friend (the bull) so that he (Dimna) might assume the bull's place of honor. Soon, however, Dimna's plot is exposed and the king orders his execution. Dimna's death is too much to bear, and his loyal friend Kalila, who had warned Dimna not to get involved with such risky machinations, dies of a broken heart. Lest we form an unfair bias against jackals, however, in a subsequent story another jackal plays the part of a humble, ascetic, vegetarian who seeks to avoid the limelight but is nevertheless drafted into the service of King Lion. Ibn Awa (the jackal) falls victim to conspirators who envy his exalted status as King Lion's friend. To his rescue comes King Lion's mother, who persuades her son of Ibn Awa's innocence. Innocence, guilt, self-sacrifice, avarice, honor, and betrayal: not a single human trait, whether virtue nor a vice, is left out of Kalila wa Dimna. That all-inclusiveness notwithstanding, certain characteristics seem to appear more frequently. In well over half of the stories, deception rules the day and these beasts, like the humans they portrary, do not have much compunction about violence as a means to an end.

In "Al-boum wa-l'ghurbaan" (The Owls and the Crows), the owls attack the crows, killing many and imprisoning many more. One of King Crow's ministers recommends appeasement, another suggests retaliation, and a third counsels retreat and emigration. The cleverest one calls for a ruse: in full view of the owls, and at his own insistence, the crows peck the clever one, pluck his feathers, and leave him injured in front of the owls' cave. When the owls interrogate him, he tells them that he had pushed for peace but that the rest of the flock had rejected his overtures for reconciliation and punished him for treason. The owls believe him, adopt him, nurse him back to health, and reveal their secrets to him. At the first opportunity, he flies back to his flock and leads them in a massacre of the owls.

While the baser instincts triumph far too often in this literature, as in life sometimes a noble character uplifts us. In "Al-Ghurab wa-asHabuhu" (The Crow and his Friends), four animals - a rat, a turtle, a crow, and a gazelle join together in the bonds of friendship and come to each other's rescue in time of need, for as the turtle reminds us at the end of the story, "Wa-maa faa'idat al-caysh bi-doun al-asHaab?" (What good is living without friends?).

As a reteller of tales, Younes has done more than merely simplify the grammar and lexicon, though these two processes contribute the most to 
this book's accessibility to intermediate students. Younes also has enlisted the artistic talents of Anees Rabie to illustrate each of the 45 stories included in this volume. The results are occasionally hilarious, but they always fit, for Rabie successfully sums up each story with a single sketch. The only problem is that his mice, rats, and rabbits look more like toads.

The author, having intermediate students in mind, has composed levelappropriate exercises at the end of each story: factual who-what-whenwhere-why-how questions, along with fill-in-the-blanks, grammatical problem solving, and open-ended questions for classroom debate. Each story teaches a moral or illustrates a human characteristic, thereby opening up an expansive field for discussion. Nevertheless, in his introduction, Younes cautions us that he does not intend his Retelling to replace an ordinary Arabic language textbook; rather, it should serve as a supplementary reader. The exercises, therefore, may be assigned or jettisoned as the teacher sees fit.

Tales ... Retold also features a nine-page Arabic-English glossary, as well as short lists following each story, with the new vocabulary and English translations. Younes has inserted four excerpts of the original Arabic rendering of Kalila wa Dimna; he then asks the student to read the classical Arabic and compare it with the simplified Modern Standard Arabic version. As a second-year Arabic student may find it difficult to make much headway through these classical Arabic texts, perhaps these readings might be saved for more advanced students. Students at all levels will benefit from the three audio CDs, which cover all 45 stories. The CD label does not mention the reader's name; perhaps we can presume the voice to be that of Munther Younes himself. Whatever the case may be, the reader pronounces Arabic eloquently and accurately. He speaks with a clear and pleasing voice at a moderate tempo. Listening to these recordings in the car during my weekly commute between Princeton University and my home in Maryland transformed 3.5 hours of tedium into an enjoyable escape into the fantasy world of talking animals!

Teachers of second- and third-year Arabic should consider supplementing their curriculum with Younes' retelling of Tales from Kalila waDimna. Not only do these stories offer a much needed break from the constant grammatical hammering of a typical university Arabic course, but they provide a glimpse into the fables that have enchanted and enthralled Arabs of all ages for more than 1,200 years. 